Nevşehir Bilim ve Teknoloji Dergisi Cilt 2(2) 21-36 2013

\title{
Folat Eksikliği ve Probiyotikler ${ }^{1}$
}

\author{
Zehra Nur YÜKSEKDAĞ ${ }^{*}$, Meryem Nur ZEYDANLI \\ Gazi Üniversitesi, Fen Fakültesi, Biyoloji Bölümü, 06500, Teknikokullar, Ankara
}

Özet

Folat, insanların canlılık faaliyetlerini sürdürmesi için çok önemlidir. Organizmanın tek karbon reaksiyonlarına katılarak, hayati faaliyetleri katalizlediğinden folat eksikliği organizma için ciddi risk taşımaktadır. İnsanlarda folat eksikliği ile ilişkili olarak birçok hastalık baş gösterebilir. İnsanlar folatı sentezleyemediğinden, dışarıdan folat bakımından zengin gıdalarla ve folik asit takviyesi ile folat ihtiyaçlarını gidermektedirler. Bu nedenle diyette sık tüketilen gıdaların folat bakımından zengin olması önem kazanmaktadır. $\mathrm{Bu}$ amaçla gıdalardaki folat miktarını arttırıcı etkenler belirlenip gıdalarda folat miktarının arttırılması sağlanabilir. Yoğurt gibi fermente gıdalardaki folatın etkenleri olan probiyotik laktik asit bakterilerinin bu amaca hizmet edebileceği düşünülmektedir. Yüksek folat üreten probiyotik suşlarla üretilen fermente gıdaların tüketimi ile insanlardaki folat eksikliğinin görülme sıklığ1 azaltılabilecektir.

Anahtar Kelimeler: Folat, folat eksikliği, probiyotik, laktik asit bakterileri

\section{Folate Deficiency and Probiotics}

\section{Abstract}

Folate is very important for people to continue the activities of vitality. The main reason for this participate the one carbon reactions of the organism. When these reactions are to catalysis the vital activity, folate deficiency is a serious risk to the organism. Even occur in many diseases associated with folate deficiency in people. Hence people cannot synthesize folate, folate-rich foods and folic acid supplements with the outside must be obtained. Therefore its importance gaining from folate-rich foods frequently consumed in the diet. For this purpose, increasing factors the amount of folate in foods can be identified, increasing the amount of folate in foods can be provided. Folate agent such as probiotic lactic acid bacteria in fermented foods (especially yogurt) are thought to serve this purpose. Fermented foods which are produced by probiotic high folate producing strains will reduce the prevalence of folate deficiency in people.

Keywords: Folate, folate deficiency, probiotic, lactic acid bacteria

\footnotetext{
"e-mail: zehranur@gazi.edu.tr

${ }^{1}$ Bu çalışma Gazi Üniversitesi Fen Bilimleri Enstitüsü Biyoloji Anabilim Dalında Doç. Dr. Zehra Nur Yüksekdağ danışmanlığı altında Meryem Nur Zeydanlı tarafından yapılan "Geleneksel Yöntemlerle Yapılan Yoğurtlardan İzole Edilen Lactobacillus delbruckii subsp. bulgaricus ve Streptococcus thermophilus Türlerinde Folat Üretimi" adlı Yüksek Lisans tezinin Kaynak Araştırmasının bir kısmından özetlenmiştir.
} 


\section{Giriş}

Folik asit, Latince yaprak anlamına gelen "folium” kelimesinden gelmektedir [1,2]. Folik asit ve folat, B vitaminin farklı terimleridir. Sentetik form olan folik asit, besinlere zenginleştirmek maksatlı eklenmektedir ve vitamin takviyesi olarak kullanılmaktadır. Vücut, folik asiti doğal folattan daha iyi absorblamaktadır. Doğal olarak gıdalarda bulunan vitamini tanımlamak için ise sıklıkla folat terimi kullanılmaktadır. İnsanlar için temel besin öğesi olan folat suda çözünen bir vitamin olarak tanımlanmaktadır. Folatlar doğal heterosiklik bileşikler olan pteridinlerin konjuge türevleridir (Şekil 1) $[1,3]$.

Pteroil glutamik asit (Folik asit)

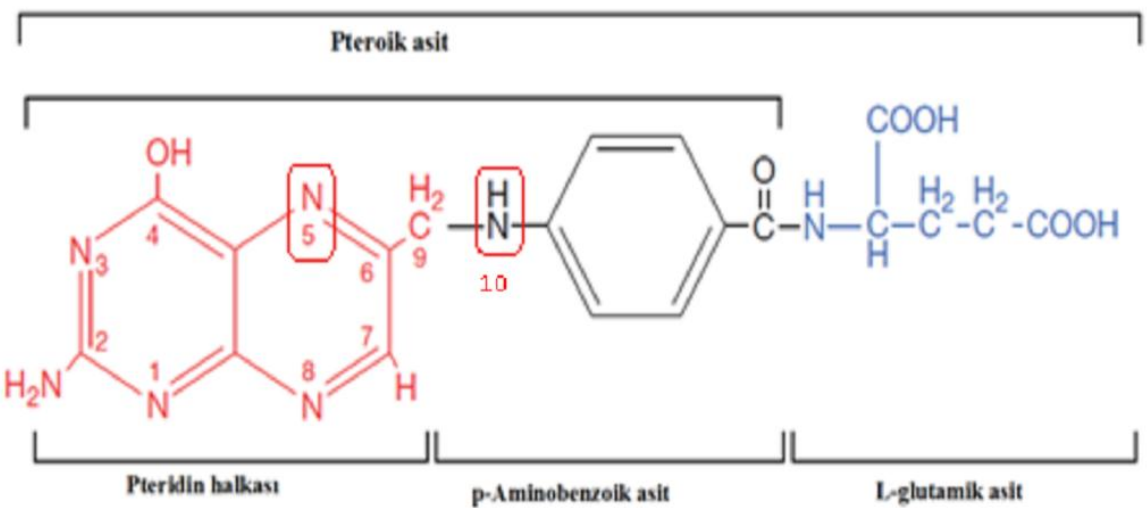

Şekil 1. Folik asitin (pteroil glutamik asit) kimyasal bileşenleri. [4].

Pteridin halkası p-aminobenzoik asit ile bağ yaparak pteroik asit meydana gelmekte, bu moleküle L-glutamik asit bağlanarak folik asit oluşmaktadır. Folat türevleri 5. ve 10. pozisyondaki azotlara bağlanan gruplarla oluşmaktadır [4]. Pteridinler, birçok biyokimyasal yolakta önemli rolü olan doğal heterosiklik bileşiklerdir. Azotlu bisiklik halka sistemi olan pirazino-[2,3-d]-pirimidin yapısına sahiptirler. Pteridin halkasının ikinci konumunda amino grubu, dördüncü konumunda okzo bulunduğunda bu yapıya "pterin" adı verilmektedir (Şekil 1) [3].

Tablo 1. Folat türevleri: tek karbon birimlerinin pteroik asite bağlanma konumu, adlandırılması, kısaltması [7].

\begin{tabular}{|c|c|c|c|}
\hline Tek Karbon Birimi & N-pozisyonu & Türev & Kisaltma \\
\hline$-\mathrm{CH}_{3}$ & $5-$ & 5-metil-tetrahidrofolat & $5-\mathrm{CH}_{3}-\mathrm{THF}$ \\
\hline -CHO & $5-$ & 5-formil-tetrahidrofolat & 5-CHO-THF \\
\hline$-\mathrm{CH}=\mathrm{NH}$ & $5-$ & 5-formimino-tetrahidrofolat & $5-\mathrm{NH}=\mathrm{CH}-\mathrm{THF}$ \\
\hline$-\mathrm{CHO}$ & $10-$ & 10-formil-tetrahidrofolat & 10-CHO-THF \\
\hline$-\mathbf{C H}=$ & $5,10-$ & 5,10-metenil-tetrahidrofolat & $5,10-\mathrm{CH}=\mathrm{THF}$ \\
\hline$-\mathrm{CH}_{2}$ & $5,10-$ & 5,10-metilen-tetrahidrofolat & $5,10-\mathrm{CH}_{2}-\mathrm{THF}$ \\
\hline
\end{tabular}


Folik asidin pteridin halkası okside formdayken, folatlar pteridin halkalarında 2 veya 4 ek hidrojen taşırlar ve sırasıyla dihidrofolat (DHF, $\mathrm{H}_{2}$ PteGlu) veya tetrahidrofolat (THF, $\mathrm{H}_{4}$ PteGlu) olarak isimlendirilir. Pteroil grubunun $\mathrm{N}^{5}$ - ve $\mathrm{N}^{10}$ - pozisyonuna 5 farklı tek karbon birimi bağlanabilmektedir ve metil, formil, formimino, metilen veya metenil türevleri oluşmaktadır (Tablo 1) [5,6].

Folat oksidasyonu; ya kofaktörün dihidro formlarının (DHF veya 5-metil-DHF) oluşumuyla yada dihidrofolat ve tetrahidrofolatın $\mathrm{C}^{9}-\mathrm{N}^{10}$ bağının oksidatif parçalanması sonucu pterin türevi ve $\mathrm{p}$ aminobenzoilglutamatın (pABG) oluşumuyla olmaktadır [5,7]. Stabilite, glutamik asit sayısından bağımsız pteridin halka sisteminin kimyasal bileşimine bağlıdır. Buna göre, folat türevlerinin stabilite sıralamas1 5-formil-THF > 5-metil-THF > 10-formil-THF > THF şeklindedir. Ortamda tiyol içeren antioksidanların veya askorbik asidin uygun miktarda bulunması folatları stabilize etmektedir. Oksijen varlığında folatın bozunma reaksiyonu folat türevlerinin türüne, gıda matriksinin yapısına, ortamın pH'sına, eser element ve antioksidanların varlığına bağlıdır [8].

Canlılar için folat türevlerinin oldukça önemli rolü vardır. Bunların vücuda alınımı da önem kazanmaktadır. Gıdalarda folatın büyük kısmı poliglutamat şeklinde bulunmaktadır. Diyetsel poliglutamil folatlar absorbsiyon öncesinde pteroilpoliglutamat hidrolaz (PPH) ile enzimatik olarak monoglutamil formlarına hidroliz olmak zorundadır. Konjugaz $(=\gamma$-glutamil hidrolaz $=\gamma$-glutamil karboksipeptidaz=folipoliglutamat karboksipeptidaz) olarak da bilinen PPH, insanda folat hidrolizinin ana bölgesi olan jejunal mukozanın firça yüzey membranlarında en yüksek aktivitededir [9-11]. İnsanlarda folat absorbsiyonu çoğunlukla jejunal mukozanın firça yüzey membranlarında gerçekleşmektedir. İnsanlarda pankreatik salgıda ve safrada daha düşük PPH aktivitesi bildirilmiştir. Fırça yüzey PPH için optimum pH 6,5-7,0 iken tüm bağırsakta folat transportu için optimum pH yaklaşık 6,0-6,3’tür [12]. İnce bağırsakta absorbe olduktan sonra portal dolaşıma geçen folatın büyük kısmı karaciğer tarafından tutulmaktadır. Karaciğerde poliglutamat türevlerine metabolize olabilir, tutulabilir veya kan veya safraya salınabilir. Ardından folatın bir kısmı enterohepatik siklusa girer [13].

Pteroilmonoglutamatlar başta 5-metil-THF olmak üzere folatın dolaşımdaki formudur. Yetişkinlerde plazma 5-metil-THF değerinin 3-30 ng/mL gibi oldukça geniş bir yelpazede olduğu bildirilmektedir $[1,13,19]$. Plazma folatının \%30-40’1 başta albumin olmak üzere düşük afiniteli bağlayıcı proteinlere $\left(\mathrm{K}_{\mathrm{d}}\right.$ folat $\left.\sim 1 \mathrm{mM}\right)$ bağlıdır. Plazma aynı zamanda düşük düzeylerde yüksek afiniteli folat bağlayıcılar $\left(\mathrm{K}_{\mathrm{d}}\right.$ folat $\left.\sim 1 \mathrm{nM}\right)$ da içermektedir [10,13,14]. Bağlayıcı proteinler, $\alpha_{2}$-makroglobulin ve transferrindir. Folat eksikliği durumlarında yüksek afiniteli folat bağlayıcı proteinlerin oranı azalır ve artan bağlanma $\alpha_{2}$-makroglobulinden transferine kayar [10].

Eritrositler plazmadan daha yüksek düzeyde folat içerirler. Yeterli folat düzeyi için $150 \mu \mathrm{g} / \mathrm{L}$ 'den fazla eritrositin olması gerektiği bildirilmiştir [15]. Eritrosit folatların tümünü 5-metil-THF poliglutamatlar oluşturmaktadır. Olgun eritrositler ve lenfositler, folatı depolama ve taşıma özelliğindedirler. Folat depoları eritropoez sırasında oluşmaktadır [13]. Bu nedenle folat eksikliği ilk olarak eritrositlerde ve yapım-yıkım oranının fazla olduğu kemik iliği hücrelerinde açığa çıkmaktadır $[7,13,14]$.

Folat katabolizmasında $\mathrm{C}^{9}-\mathrm{N}^{10}$ bağının kopmasıyla folatın parçalanma ürünü pterin, folat türevi aminler ve p-aminobenzoilglutamat oluşmaktadır. p-aminobenzoilglutamat'ın çoğu ( $\% 85)$ sitozolde arilamin-N-asetiltransferaz ile asetillenmekte ve idrarla atılmaktadır [16]. Memeli dokusu poliglutamat 
folat zincirini hidroliz edebilen $\gamma$-glutamil hidrolaz, çoğu memeli dokusunda lizozomlarda lokalize olmuş durumdadır [13,17]. Folat glomerülerden serbestçe süzülebilmektedir. Ancak tekrar reabsorbe olabilir. Folat türevlerinin renal krilensi böbrek proksimal tübüllerindeki folat bağımlı proteinlere bağlanma afiniteleriyle ters orantılıdır. Safra yoluyla folat atılımı insanlarda günde $100 \mathrm{~g}$ olarak bildirilmiştir. Bununla birlikte feces ile atılan folat miktarı değişkendir [7,13].

Folatın metabolik görevi çeşitli oksidasyon basamaklarında varolan tek karbon birimi taşımaktır. Tek karbon birimleri format, formaldehit veya metanol düzeyinde oksidasyonla taşınır. Tek karbon birimleri folat türevlerine katıldığında, bir oksidasyon basamağından diğerine elektron alarak veya elektron vererek geçerler [14]. Hücrede ana olarak beş tek-karbon transfer reaksiyonu gerçekleşir. Bunlar, serinin glisine dönüşümü, histidinin katabolizması, metiyonin, pürin ve timidilat sentezleridir [1]. Timidilat ve pürin nükleotitleri, DNA ve RNA sentezi ve onarımında kullanılmaktadır [18]. Hemoglobinin aminoasit bileşiminin \%10’unu histidin oluşturmaktadır. Histidin amino asidi, memeli dokusunda metabolik olarak glutamik aside dönüşmektedir [19]. Homosistein metabolizması, homosisteinin metiyonin sentaz enzimiyle metiyonine ve sistatyonin- $\beta$-sentaz (CBS) ile sisteine dönüşümünü kapsamaktadır (Şekil 2) [7,20].

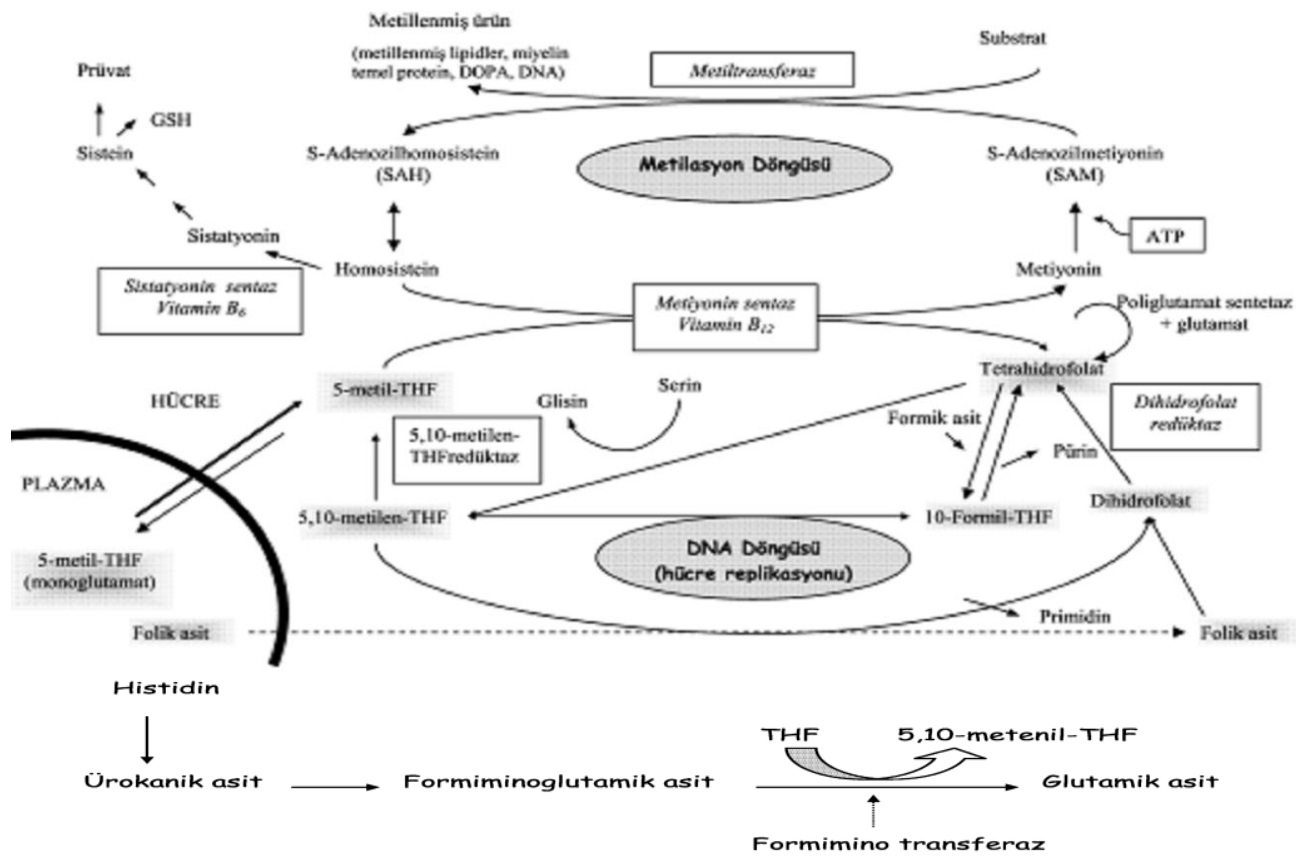

Şekil 2. Folatın tek karbon metabolizmaları. GSH: Glutatyon, ATP: Adenozin trifosfat [7]

Metilentetrahidrofolat Redüktaz (MTHFR): Folik asit metabolizmasının anahtar enzimdir. MTHFR, timidin sentezinde gerekli tek karbon donörü olan 5,10-metilen-THF'ın 5-metil-THF'a redüksiyonu için kullanılan sitozolik bir enzimdir. Bu reaksiyon NADPH'a bağımlı olarak gerçekleşir. Oluşan 5-metilTHF, homosisteinin metiyonine metilasyonu için gereklidir [21]. S-adenozilmetiyoninin (SAM) oluşumunda ilk basamak ise metiyonin oluşumudur. SAM ise DNA, proteinler, nörotransmitterler ve fosfolipitlerin metilasyonunda, metil grup donörü olan esansiyel bir substrattır [22]. MTHFR eksikliği hiperhomosisteinemi (kanda yüksek düzeyde homosistein bulunması) ve homosisteinüri (sistatiyonin beta sentaz eksikliğiyle karakterize olan otozomal resesif hastalık) ile sonuçlanmaktadır. Diğer taraftan MTHFR eksikliğinin metilentetrahidrofolatı arttırarak timidilat sentezi için daha fazla tek karbon grubu 
sağlayabileceği de düşünülmektedir [23]. MTHFR eksikliğinden pürin ve pirimidin biyosentezi etkilenmediği için megaloblastik anemi oluşmamaktadır (Şekil 2). MTFHR eksikliği, plazma homosistein seviyesinin yükselmesine bu da kardiovasküler hastalıkları ve nöral tüp defekti (NTD) riskinin artmasına neden olmaktadır [7,24].

Metiyonin Sentaz (MS): 5-metil-THF'ın metil grubunun homosisteine transferini kolaylaştırarak metiyonin oluşumunu sağlayan bir enzimdir. Kofaktör olarak $B_{12}$ (kobalamin)'ye ihtiyaç duymaktadır. MS eksikliği olan hastalarda 5-metil-THF birikir. 5,10-metilen-THF'in 5-metil-THF'a dönüşümü devam edeceğinden, metilen, metenil ve formil-THF azalır. "Metil-folat tuzağı" olarak adlandırılan bu durumda kaçınılmaz olarak pürin ve pirimidin sentezi dolayısıyla DNA sentezi azalmakta ve sonuçta megaloblastik anemi oluşmaktadır (Şekil 2) $(24,25)$.

Metiyonin Sentaz Redüktaz (MSR): Metiyonin sentazın redüktif aktivasyonunu katalizlemektedir. Annede kobalamin konsantrasyonu yetersiz ise, MSR enzimindeki polimorfizmin nöral tüp kusuruna yol açabileceği öngörülmüştür (Şekil 2) [21,24].

Dihidrofolat Redüktaz (DHFR): Dihidrofolatın tetrahidrofolata redüksiyonunu sağlayan enzimdir. DHFR inhibitörleri DNA, RNA ve protein sentezlerini durdurarak hücre gelişimini engellemektedir. DHFR bakteri, protozoa ve mantarlarca oluşan çeşitli enfeksiyonların ve kansere karşı geliştirilen ilaçların önemli bir hedefidir (Şekil 2) [4,26].

Timidilat Sentaz (TS): Timidilat döngüsünde 5,10-metilen-THF'ın DHF'a dönüşümünde rol alır. TS deoksi-timidilat (dTMP) sentezi için de novo yolağındaki tek enzimdir (Şekil 2) [25].

Dengesiz ve yetersiz beslenme çağımızın sorunu haline gelmiştir. Folat eksikliğinin birçok nedeni olmakla birlikte eksikliğin oluşma nedenlerinden biri olarak beslenme bozuklukları sayılmaktadır. Gelişmekte olan çocuklarda ve hamile bayanlarda bu eksiklik ciddi riskler taşımakla birlikte folat bakımından zengin gıdaların tüketimiyle eksiklik azaltılabilmektedir. Böylece canlının folatı kullandığı metabolizma faaliyetler sorunsuz bir şekilde yapılacaktır [5,27].

\section{Folat Eksikliğine Bağlı Olarak Oluşan Bazı Hastalıklar}

\subsection{Nöral Tüp Defekti}

Nöral tüp defektleri fetüs gelişiminin erken döneminde ortaya çıkan ve değişik şiddet derecelerinde yaşam boyu komplikasyonlara neden olabilen bozukluklar grubudur. Gelişmesinin ilk 3-4 haftası içinde zigot içindeki spesifik hücreler sarmallaşır ve kenarları kaynaşarak omurilik, beyin, çevrelerini saran kemik ve dokuların temelini oluşturan dar bir tüp meydana getirir. Bu nöral tüpün oluşum süreci genellikle gebeliğin (gestasyonun) 28. gününe doğru, hatta birçok kadın gebe kaldığını anlamadan önce tamamlanmış olur. Tüp tüm uzunluğu boyunca uygun biçimde kapanmamış olursa açık bir yerden bir NTD oluşacaktır. Normalde omurilik ve beyin, beyin-omurilik sıvısı (BOS) tarafından sarılıp desteklenmekte, meninksler denilen dış doku katmanlarıyla korunmaktadır. Beyin ayrıca kafatasıyla, omurilik ise esnek bir koruyucu katman oluşturan omurlarla korunmuştur. Hastada NTD varsa beyin ve omuriliğin korunmasında bir veya birden fazla sayıda açık alan mevcuttur. Bu durum beynin gelişmesini olumsuz etkileyebilmekte ve omuriliği hasarlanmaya karşı korunmasız bırakmaktadır. Omurilik vücut hareketlerini kontrol eden sinirleri içermektedir. Oluşan herhangi bir hasar, eşlik eden 
kasları ve organları felç edebilir veya güçsüzleştirebilir. Spinal disrafizm de denilen spina bifida NTD'nin en s1k görülen tipidir. Nöral tüp omurga boyunca bir bölgede tamamen kapanmadığında spina bifida oluşmaktadır. Hastalık bulguları kişiden kişiye ve zamanla değiş̧ebilmektedir. Spina bifida kısmen veya tamamen vücudun alt bölümünün güçsüzlüğüne, his kaybına veya felcine yol açabilmektedir [28].

Folat ve folik asit alınımı DNA üretimi ve hücre büyümesi ile ilgilidir, üreme çağındaki tüm kadınlarda yeterli düzeyde folik asit/ folat alınımı esastır ve nöral tüp defektleri \%70'e kadar azaltılabilir [7]. Nüfus yoğunluğu fazla olan ve gelişmiş bir ülke olan ABD'de yılda 3000 gebelik nöral tüp defektinden (NTD) etkilenmektedir. Ülkemizde ise, nöral tüp defekti ortalama 1000 canlı doğumdan üçünde görülmektedir [29,30].

Folat eksikliğinin NTD gelişimi üzerindeki etkileri konusunda iki temel hipotez vardır. Her ikisinde de NTD oluşumunu etkileyen mikro besin ve genetik faktörler üzerinde durulmaktadır. İlk hipotezde, düşük serum folat düzeyi durumunda, folik asidin embriyonun hücrelerine sinırlı olarak ulaşması nedeniyle normal hücre fonksiyonlarının bozulduğu ve proliferasyonun sınırlandığı ileri sürülmektedir. Folik asit yetersizliğinde metiyonin yapımı azalır, hücre içi S-adenosilmetiyonin düzeyi düşer. $\mathrm{Bu}$ da DNA da sitosin ve timinin metilasyonunu bozarak uygunsuz proto-onkojenlerin aktivasyonuna yol açar, malignant dönüşümünü uyarır ve mutant gen oluşumunu önleyemez. Timidilat yapımının sınırlanması da hatalı DNA yapımına yol açarak megaloblast oluşumunu uyarır. Ayrıca folik asit eksiliğinde hücreler bölünme durumunda metafaz ve anafazda ilerleyemez. İkinci hipoteze göre ise, folik asit eksikliğinde plazma homosistein seviyesi artar. Homosistein de nöral epiteldeki N-metil-Dasparat reseptörlerini baskılayarak nöral tüpün kapanmasına engel olur [31].

\subsection{Anemi}

NTD dışında folat eksikliğine sebep olan bir diğer önemli ve sık görülen hastalık megaloblastik anemidir. Bu patoloji plazmatik folatın yetersiz miktarda bulunması sonucu olarak, DNA sentezi noksanlıkları meydana gelir. DNA replikasyonundaki bu azalma eritropoiezis (eritrosit üretimi) boyunca hemoglobinin düşük üretimine neden olur, anormal olarak büyümüş eritrositlerin (megalositler) varlığ düşük hemoglobin konsantrasyonu ve diğer hematolojik değişimlerle kendini gösterir. Megaloblastik anemi sadece folat eksikliğine değil aynı zamanda B12 vitaminin eksikliğinin de sebeptir [4].

\subsection{Kanser}

Folat eksikliği oluşturulan sıçanlarda karsinojeniteye karşı duyarlıllğın arttı̆̆g saptanmıştır. Folatın antikarsinojenik etki mekanizması tam olarak bilinmemekle birlikte DNA metilasyonu ile ilişkili olduğu düşünülmektedir. Folatın SAM (S-adenozilmetiyoninin) düzeyinin korunmasındaki ve DNA sentezi için gerekli deoksitimidin monofosfat üretimindeki rolü nedeniyle, eksikliğinde karsinojenezi artırabileceği düşünülmektedir. Sitozin-guanin zincirlerinde hipometilasyon durumunda spesifik onkojenlerin ekspresyonu artabilir. Diyetsel folat eksikliğiyle ilişkilendirilen DNA'nın hatalı veya eksik metilasyonu, kanser ve yaşlanmaya sebep olacak bir mekanizma geliştirdiği bildirilmektedir [32]. 
In vitro denemelerde kültür ortamında $180 \mathrm{nmol} / \mathrm{L} \quad(80 \mathrm{ng} / \mathrm{mL})$ 'den yüksek folik asit konsantrasyonlarının insan hücrelerindeki DNA kırıklarını azalttığı gösterilmiştir. İnsan lenfosit kültür çalışmasında $120 \mathrm{nmol} / \mathrm{L}$ folik asitin DNA yapısına urasil girişini en aza indirdiği gösterilmiştir [33].

\subsection{Kardiyovasküler Hastalıklar}

Düşük folat düzeylerinin serebrovasküler ve koroner arter hastalığı riskini arttırdığı bildirilmektedir. Folatın aktif formu olan 5-metil-THF'ın azalmasına neden olan 5,10metilentetrahidrofolat redüktaz (MTHFR)'daki mutasyonun, büyük olasılıkla folat durumuna bağlı olarak vasküler hastalık için risk faktörü olduğu rapor edilmektedir [34].

\subsection{Nörolojik Hastalıklar}

Alzheimer'ın nörotoksik amiloid- $\beta$-peptid adı verilen 40-42 aminoasidin oluşması ve birikmesi sonucu amiloid prekürsör proteinin anormal parçalanması sonucu oluştuğu düşünülmektedir. Alzheimer ile düşük eritrosit folat düzeyleri arasında anlamlı bir korelasyon bulunsa da, folat eksikliğinin Alzheimer hastalığı ile ilişkisi tam olarak aydınlatılamamıştır. Düşük serum folat düzeyleriyle serebral korteksde meydana gelen atrofinin ilişkisi olduğu düşünülmektedir [35]. 61-90 yaşları arasında 19 Parkinson hastasında yapılan çalışmada, folat, homosistein ve $B_{12}$ vitamini konsantrasyonları ölçülmüş, benzer yaşlardaki sağlıklı kontrol grubuyla karşılaştırılmış ve neopterin konsantrasyonu immün aktivasyon indikatörü olarak kullanılmıştır. Homosistein düzeylerinin, folat ve $\mathrm{B}_{12}$ vitamini konsantrasyonlarıyla ters orantılı olduğu, neopterin konsantrasyonuyla ise doğru orantılı olduğu rapor edilmiştir [7,35].

\subsection{Psikiyatrik Hastalıklar}

Yapılan bir araştırmada, depresyondaki hastalarda serotonin metaboliti 5-hidroksiindolasetik asit (5-HIAA) serebral spinal sıvıda azaldığı ve hastalara folat verildiğinde 5-HIAA düzeylerinin normale döndüğü ifade edilmektedir. Şizofrenik ve depresif hastalarda serum ve eritrosit folat düzeyleri ölçülmüş, eritrosit folat düzeyleri arasında fark bulunmazken, serum folat düzeyleri her iki grup hastada da kontrole göre düşük bulunmuştur [36].

\subsection{Tiroid}

Folat metabolizmasinda yer alan MTHFR, MS ve CBS (sistatyon beta sentaz) aktivitelerinin tiroid hormonundan etkilendiği bildirilmektedir. Hipertirodizmde folat düzeyinin yüksek, hipotirodizmde ise düşük olduğu vurgulanmaktadır [37].

\subsection{Glutamat Formiminotransferaz Eksikliği}

Glutamat formiminotransferaz eksikliği otozomal çekinik bir hastalıktır. Hafif ve şiddetli olarak 2 fenotipi bulunmaktadır. Folat metabolizmasında ikinci en yaygın görülen doğuştan kusurdur. Glutamat formiminotransferaz-siklodeaminaz (FTCD) enziminin formiminotransferaz kısmı Nformiminoglutamatın formimino grubunun THF'a transferini katalizler ve glutamatı serbest bırakırken siklodeaminaz kısmı formimino-THF'dan amonyağın serbest hale geçip 5,10-metenil-THF'ı oluşturur. Hastalığın hafif formunda formiminotransferaz reaksiyonunun bloke olmasıly tüm FIGLU 
(formiminoglutamik asit) idrarla atılır, şiddetli formu olan siklodeaminaz reaksiyonunun bloke olmasıyla bir kısım FIGLU 5-formimino-THF'a dönerek idrarda FIGLU düzeyi azalır [7,38].

\section{Folat Analiz Yöntemleri}

Biyolojik numunelerin folat analizi için mikrobiyolojik, radyoassay, yarışmalı protein bağlama, yüksek performanslı sıvı kromatografisi, gaz ve sıvı kromatografisi/kütle spektrofotometresi yöntemi gibi çeşitli teknikler kullanılmaktadır [7,39].

\subsection{Mikrobiyolojik Yöntem}

Folatın mikrobiyolojik yöntemle analizi yapısal özellikleri aydınlatılmadan önce yapılmaya başlanmıştır. Mikrobiyolojik yöntem oldukça ucuz ve duyarlıdır. Bu yöntemde folat ve folat türevlerine duyarlı ve bağımlı bakteri (Lactobacillus rhamnosus ATCC 7469) kullanılmakta ve folat miktarına bağlı artış gösteren bakterilerin bulanıklığı spektrofotometrede geçirgenlik ölçülerek kalibrasyon doğrusu hazırlanmaktadır [6,14]. L. rhamnosus ATCC 7469 biyolojik aktif folatlara spesifiktir. Rutin folat analizleri için uygun bir yöntem olmasına karşın deney ortamı gerekli derecede tamponlanmadığında örnek içindeki bileşenler pH'yı dolayısıyla bakteri artışını etkilemektedir [40,41]. Poli- $\gamma$-glutamatların deney öncesi dekonjuge edilmesi gerekmektedir aksi takdirde bakterilerin folata cevabı büyük oranda azalmaktadır [7].

\subsection{Radyoassay Yöntemi}

İşaretli ve işaretsiz folatlar sınırlı sayıdaki folat bağlayıcı proteinin bağlanma bölgeleri için yarışırlar. Kompetetif ve kompetetif olmayan iki farklı radyoassay uygulaması vardır. Kompetetif sistemde işaretli folatın bağlanması izlenir. İşaretli olmayan folatın konsantrasyonundaki artışla işaretli folatın konsantrasyonu ters orantılıdır. Bu şekilde doz cevap eğrisi hazırlanarak biyolojik örneklerdeki folat konsantrasyonu bulunabilir. Kompetatif olmayan sistemde ise, numune folat bağlayıcı proteinle inkübe edilir. Bağlayıcı proteinin işgal edilmemiş bölgelerine işaretli folatın bağlanması sağlanır. Bağlanmamış folat uzaklaştırılır ve bağlı folatın radyoaktivitesinden yararlanılarak miktar tayini yapılır [7,42].

\subsection{Yarışmalı Protein Bağlama Yöntemi}

Yarışmalı protein bağlama yöntemi ile folik asit analizinde, ticari kitler mevcuttur. Folat analizinde bağlayıcı olarak kullanılan sütte doğal olarak bulunan $\beta$-laktoglobülin veya süt folat bağlayıcı olarak da isimlendirilen bir protein kullanılmaktadır. Bu yöntem daha çok serum folat analizinde kullanılmaktadır. $\mathrm{Bu}$ yöntem folatın (özellikle 5-metil-THF) ve $\mathrm{I}^{125}$ işaretli folatın sınırlı sayıdaki bağlanma bölgesi için yarışarak $\beta$-laktoglobüline bağlanması esasına dayanır. Uygun çözelti kullanılarak serbest folatın bağlı folattan ayrılması sağlanmaktadır [43].

\subsection{Yüksek Performanslı Sıvı Kromotagrafisi (HPLC)}

HPLC oldukça hassas ve güvenilir bir analizdir. Folat analizinde dokuların ve biyolojik sıvıların konjugazla muamele edilmesinin ardından HPLC yöntemi ile toplanan fraksiyonlarda folat türevlerinin 
miktar tayini yapılabilir. Fluoresans veya elektrokimyasal dedektörler kullanılır. Folat kofaktörlerini ayırmak için olduğu kadar, formülasyonlardaki veya gıdalardaki folat miktarlarının, karaciğer gibi bazı biyolojik materyalde belirlenmesinde daha sık kullanılmaktadır. HPLC analizinde bildirilen deteksiyon limitleri $0,1-100 \mathrm{ng} / \mathrm{mL}$ aralığında değişmektedir. [7,44-46]. Her türlü biyolojik materyaldeki folat miktarını belirlenmesini sağlayan yüksek performaslı sıvı kromatografisi yöntemi oldukça hassas bir yöntem olması yanında maliyeti yüksektir.

\subsection{Gaz Kromatografisi ve Sıvı Kromatografisi/Kütle Spektrofotometresi GC/MS ve LC/MS}

İnsanlarda yapılan çalışmalarda stabil izotopların kullanımı folatın oral ve/veya intravenöz test dozlarının metabolizması ve absorbsiyonunu hesaplamaya veya vücuttaki mevcut doğal folatın miktarını ölçmede yardımcıdır. GC/MS dezantajı ekstraksiyon, saflaştırma ve türevlendirme prosedürü çok zaman almaktadır. Ayrıca madde kaybı tehlikesi uygun uçucu türevlerinin oluşturulması sırasında birçok aşama ve kimyasal reaksiyonlarla artmaktadır. LC/MS analizi öncesinde örneklerin saflaştırılması için folat bağlayııı protein afinite kolonu kullanılmaktadır [47].

\section{Folat Kaynakları}

Memeli hücreleri folik asidi sentezleyemez. Bu nedenle ekzojen kaynakların tüketimi mecburidir [27]. Kırmızı ve beyaz et, baklagiller, yeşil yapraklı sebzeler, narenciye, bazı meyveler, sebze, et ürünleri ve fermente süt ürünleri gibi birçok besinde folat bulunmaktadır (Tablo 2) [9].

Tablo 2. Günlük diyette tüketilen katı gıdalardaki folat miktarının gıda miktarına göre değeri ( $\mu \mathrm{g} / \mathrm{g})$ [49].

\begin{tabular}{|c|c|c|c|c|c|}
\hline Gida & Gıda Miktarı (g) & $\begin{array}{c}\text { Folat Miktarı } \\
(\mu \mathrm{g})\end{array}$ & Gida & Gida Miktarı (g) & $\begin{array}{c}\text { Folat Miktarı } \\
(\mu \mathrm{g})\end{array}$ \\
\hline Alabalık & 100 & 750 & Corn flakes & 28 & 222 \\
\hline Pirinç & 185 & 716 & Kırmızı et & 85 & 221 \\
\hline Hindi & 145 & 486 & Soya fasulyesi & 180 & 200 \\
\hline Tavuk & 145 & 373 & Çubuk kraker & 60 & 172 \\
\hline Un & 125 & 364 & Kuru fasulye & 262 & 170 \\
\hline Mercimek & 198 & 358 & Maydanoz & 100 & 170 \\
\hline Barbunya & 171 & 294 & Brokoli & 159 & 168 \\
\hline Nohut & 164 & 282 & Spagetti & 140 & 167 \\
\hline Fistık & 100 & 280 & B.lahanası & 156 & 157 \\
\hline Bamya & 184 & 269 & Karaciğer & 100 & 140 \\
\hline Ispanak & 180 & 263 & Böbrek & 100 & 60 \\
\hline Piliç & 100 & 250 & Muz & 100 & 20 \\
\hline Kuşkonmaz & 180 & 243 & Yumurta & 100 & 20 \\
\hline
\end{tabular}

Mikroorganizmalardan da bazı laktik asit bakteri türleri intrasellüler ve/veya ekstrasellüler folat üretme yeteneğine sahiptir [48]. Folat bakımından zengin diyet kaynakları maya ekstraktı, karaciğer, böbrek, baklagiller, yeşil yapraklı sebzeler ve turunçgiller, 100 g’ında $600 \mu \mathrm{g}$ gibi yüksek oranda folat bulundurduğu bildirilmiştir [5]. Ekmek, patates ve süt ürünleri gibi çok miktarlarda tüketilen gidalar daha az folat içermelerine rağmen total folat alınımının önemli bir kısmını oluşturmaktadırlar [1]. Sütün 
litresinde yaklaşık 20-50 $\mu \mathrm{g}$ folat bulunmakta ve günlük folat gereksiniminde önemli katkısı vardır. Bazı fermente süt ürünlerinin, özellikle yoğurdun oldukça yüksek folat içeriğine sahip olduğu bildirilmiştir. Yoğurt litrede $110 \mu \mathrm{g}$ 'a kadar folat içermektedir. Bu yüksek folat içeriği doğrudan yoğurttaki probiyotik laktik asit bakterilerinden kaynaklanmaktadır [48].

\subsection{Probiyotikler}

Bağırsak sisteminde bulunan faydalı mikroorganizmaların gıdaların sindirimine yardımcı olmak, canlıyı patojen mikroorganizmalardan korumak ve canlının savunma mekanizmasını desteklemek gibi işlevleri vardır. Doğumdan hemen sonra ortamdan, anneden ve anne sütünden kazanılan doğal floradaki ana grubu laktik asit bakterileri (LAB) ve bifidobakteriler oluşturmaktadır. Bu bakteriler, bağırsak florasını düzenleyerek konakçı sağlı̆̆ı üzerinde faydalı etkileri olduğundan 'probiyotik' olarak tanımlanmaktadır [50].

Probiyotik olarak çok sık kullanılan laktik asit bakterileri, gıda ürünlerinin besin değerine ve besinlerin biyolojik yolla korunmasına olumlu katkıda bulunmaları nedeniyle yüzyıllardır önemini koruyan mikroorganizmalardır. LAB'ın çoğu; insan, hayvan ve bitkilerin bulunduğu doğal ortamlarda bulunan, bu ortamlardan izole edilebilen, biyoteknolojik çalışmalarda ve endüstriyel birçok alanda kullanılan, insan beslenmesinde ve sağlı̆̆ında oldukça önemli mikrobiyal ajanlardır. Süt, et, balık, tahıl ve sebze gibi çoğu ham gıda maddelerinin fermentasyonla korunmasında, üretilen fermente gıda ve yemlerin organoleptik (duyu organlarını uyarıcı), reolojik (akışkanlık) ve besinsel değerine katkıda aktif rol üstlenmektedirler [51,52]. LAB, fermentasyonunda starter kültür olarak rol aldıkları gıdalarda aroma ve tekstürün oluşmasına katkı sağlamaktadırlar. Ayrıca gıdalarda bazı patojenlerin gelişimini inhibe etme özelliklerinden dolayı da insan sağlığı açısından fonksiyonel önem arz etmektedirler [4,53].

Birçok LAB türlerinin folat üretim yetenekleri araştırılmıştır. Lactococcus lactis, Streptococcus thermophilus ve Leuconostoc cinsine ait türlerin folat üretebildiği, buna karşın Lactobacillus plantarum türüne ait suşların folat üretme yeteneğinin olmadığ bildirilmiştir. L. plantarum türünde folat üretimi olmamasının sebebinin biyosentezden sorumlu genlerin genomda bulunmaması olduğu ifade edilmektedir $[48,54]$.

Folat üretebilen laktobasil türlerinde çok farklı konsantrasyonda folat üretim yeteneği olmaktadır. Kimyasal olarak tanımlanmış folat içermeyen besiyerinde (CDM) bazı laktobasillerin folat üretim yeteneğinin düşük olduğu, buna karşın $L$. delbrueckii ssp. bulgaricus türüne ait suşlarda diğer türlere oranla yüksek sentezleme yeteneği olduğu bildirilmiştir [4,48,54,55]. Folat üretim yeteneğine sahip olan bazı mikroorganizmalar da Tablo 3'de verilmiştir.

Önemli bir probiyotik ürün olan yoğurtun starter kültürleri olan S. thermophilus ve L. delbrueckii ssp. bulgaricus türlerinde üretilen folat miktarının daha yüksek olduğu bildirilmektedir (Tablo 3) [56]. İdeal yoğurdun her gramında, folat üretme yeteneği yüksek olan $10^{8}-10^{9}$ canlı $S$. thermophilus ve L. delbrueckii ssp. bulgaricus starter kültürleri bulunmaktadır [57]. Çeşitli çalışmalarda fermente süt ürünlerinde Lactobacillus suşlarından 
Nevşehir Bilim ve Teknoloji Dergisi Cilt 2(2) 21-36 2013

Tablo 3. Folat üreten mikrorganizmaların folatsız kimyasal besiyerinde belirlenen folat üretim miktarları (ng/g) [54,55].

\begin{tabular}{|c|c|c|}
\hline \multicolumn{2}{|c|}{ Mikroorganizmalar } & \multirow{2}{*}{$\begin{array}{c}\text { Folat Üretim Miktarı (ng/g) } \\
2-89 \\
\end{array}$} \\
\hline \multirow{8}{*}{ Lactobacillus türleri } & L. helveticus & \\
\hline & L. acidophilus & $48-69$ \\
\hline & L. casei & $3-10$ \\
\hline & L.casei ssp. rhamnosus & $0-10$ \\
\hline & L. delbrueckii ssp. bulgaricus & $60-100$ \\
\hline & L. reuteri & $0-10$ \\
\hline & L. fermentum & $2-10$ \\
\hline & L. johnsonii & $4-10$ \\
\hline \multirow{6}{*}{ Bifidobacterium türleri } & B. animalis & $15-25$ \\
\hline & B. bifidum & $5-6$ \\
\hline & B. breve & $40-55$ \\
\hline & B. infantis & $25-45$ \\
\hline & B. longum & $9-12$ \\
\hline & B. lactis & $20-30$ \\
\hline Streptococcus türleri & S. thermophilus & 29-202 \\
\hline Enterococcus türleri & E. faecium & $18-28$ \\
\hline \multirow{3}{*}{ Lactococcus türleri } & L. lactis ssp. cremoris & $12-92$ \\
\hline & L. lactis ssp. lactis & $13-57$ \\
\hline & L. lactis ssp. diactylactis & $79-100$ \\
\hline \multirow{4}{*}{ Propionibacterium türleri } & P. thoenii & 36 \\
\hline & P. acidipropionici & 36 \\
\hline & P. jensenii & 40 \\
\hline & P. freudenreichii ssp. shermanii & $17-78$ \\
\hline \multirow[t]{2}{*}{ Leuconostoc türleri } & L. lactis & 45 \\
\hline & L. paramesenteroides & 44 \\
\hline
\end{tabular}

yararlanılarak folat takviyesinin yapılabileceği bildirilmektedir ve folat üretimi ve kullanımı için Lactobacillus sp. ve S. thermophilus karışık kültürlerinin kullanılması önerilmektedir [58]. Böylece, folat düzeyi artan yoğurt ve fermente süt ürünleri elde edilebilecektir. Lactococcus lactis ve Streptococcus thermophilus gerçekleştirdiği folat üretimiyle, vitamini hücre içinde biriktirirler ve besiyerine salgılarlar. Folat üretim kapsamı, birikim ve salgılama olarak bölünür ve folat oluşması (örneğin, glutamat residü 
sayısı ve formil veya metenil grupların varlığı) çoğunlukla suşa bağlı olarak değişir. Folat oluşumu aynı zamanda pH, büyüme hızı ve pABA varlığg gibi kültür koşullarıyla da değişmektedir [58]. Fermente süt ürünlerinin baskın folat üreticilerinden olan S. thermophilus suşlarında 12 saatlik fermentasyon sonrası Bifidobacterium animalis suşuna göre 5-MTHF üretiminin altı kat daha fazla olduğu bildirilmiştir [59]. S. thermophilus'da tespit edilen 5-formil-THF ve 5,10-metenil-THF'ın çoğunu hücre dışına saldığı ve intra ve ekstrasellüler folat dağılımının $\mathrm{pH}$ ile etkilendiği rapor edilmektedir. Hücrelerin yüksek $\mathrm{pH}$ kültürlerine nazaran düşük pH gelişiminde daha yüksek oranda ekstrasellüler folat üretim yeteneğine sahip oldukları bildirilmektedir [54].

Son y1llarda, laktik asit bakterilerinin giderek artan genom sekans analizi ile, bu bakterilerin folat biyosentezi ile ilgili önemli bilgiler edinilmesine katkı sağlanmış, genom sekanslanması sınırlı sayıda olsa bile, tüm türlerin karşılaştırılması yapılmıştır [58]. Lactococcus lactis gibi L. delbrueckii, L. reuteri, L. helveticus ve L. fermentum türlerinde, folat biyosentez bölgelerinde dihidropteroat sentaz (EC 2.5.1.15) ve alkalin fosfataz (EC 3.1.3.1) hariç DHPPP (6-hidroksimetil-7,8-dihidropterin pirofosfat) biyosentezi için gerekli tüm genler kodlanmıştır. L. lactis'de dihidroneopterin trifosfatın monofosfata defosforilasyonuyla Nudix pirofosfohidrolaz dahil alternatif bir yol olduğu gösterilmiştir [60]. Birçok laktobasillusun kodladığı Nudix enzim genleri (DNA tamiri için gerekli mutT geni de dahil), sadece $L$. helveticus ve L. delbrueckii'de L. lactis'in fol gen bölgesine homolog olduğu bulunmuştur. L. fermentum ve $L$. reuteri' de çeşitli şekillerde fol gen bölgesinde non-Nudix pürin NTP-pirofosfataz bulunmaktadır ve bu türlerde dihidroneopterin trifosfatın hidrolizinden sorumlu olduğu düşünülmektedir. $\mathrm{Bu}$ nedenle $L$. delbrueckii, L. reuteri, L. helveticus ve L. fermentum DHPPP üretmesi beklenmektedir ve DHPPP üretimi folat üretiminin kilit noktası sayıldığından, pABA varlığında kültüre edildiklerinde potansiyel folat üreticisi oldukları düşünülmektedir [58]. Kofaktör ve vitaminlerin alt kategori metabolizmasında referans metabolik yolakta var olan enzimlerin genom karşılaştırılması mümkündür, böylece spesifik mikroorganizmaların laboratuvar deneyleri gerçekleştirilmeden folat biyosentez yeteneklerini belirlemek mümkün olabilecektir [61]. Entegre Mikrobiyal Genomları (IMG) sistemine göre, 250'den daha fazla mikrobiyal genom verileri (20’den fazlası LAB genomunu içerir) sekanslanarak başka pek çok proje için gerekli yapılanma tüm dünya ile paylaşılmaktadır [62].

Probiyotik bakterilerin insana kattığı bir diğer olumlu etkisi, kolon epitelindeki lokalizasyonu sayesinde, folat eksikliğiyle beraber gelişebilecek kolon epitelindeki premalign değişimleri önlemesidir. Oral yolla alınan folat üreten probiyotiklerin, inflamasyon ve kansere karşı daha etkili bir koruma ve yararlı etkiler sağlayabildiği, ayrıca kolonik rektal hücrelere folat temin ettiği ifade edilmektedir [63]. İnsanlarda toplamda absorbe edilen folatın az sayıda kaynaklardan temin edildiği belirtilmektedir [55]. Bu yüzden günlük diyette folat bakımından yüksek gıdaların, özellikle de yoğurdun, tüketimi önem kazanmaktadır.

\section{Sonuç}

Folat eksikliği organizmanın önemli metabolik faaliyetlerini sürdürülemesine engel olmakta ve çeşitli rahatsızlıkların oluşmasına neden olmaktadır. Özellikle DNA sentezine katılması, hamileliğin erken dönemlerindeki bebeklerin ve ergenlik dönemindeki çocukların gelişimi açısından oldukça önem taşımaktadır. Günlük diyette, sürekli olarak tüketilen besinlerin folat içeriğinin yüksek olması folat 
eksikliği ile mücadele açısından oldukça önemlidir. Starter kültür olarak probiyotik bakterilerin kullanıldığı ve folat ile güçlendirilmiş fermente gıdaların kullanımıyla folat eksikliği ile mücadele edilebilir. Özellikle yüksek folat üretimine sahip probiyotik mikroorganizmaların tüketimi, dışarıdan folik asit takviyesine gerek duyulmadan folat eksikliğinin doğal yolla giderimi sağlanabilecektir. Genom sekanslama veritabanları kullanılarak farklı probiyotik suşlarının folat üretim yetenekleri ve buna bağlı olarak metabolik mekanizması kolayca anlaşılabilecektir. Çağımızın en büyük sorunu haline gelen kanserin toplumdaki prevalansını azaltmak amacıyla tüketilen fermente gıdalardaki probiyotiklerin yüksek miktarda folat üretmesi ile homeostaziye olumlu etkisi, bilim dünyasında büyük ilgi uyandırabilir.

\section{Kaynaklar}

[1] Lucock M., "Folic acid: nutritional biochemistry, molecular biology, and role in disease processes”, Molecular Genetics and Metabolism, 71(1-2), 121-138, 2000.

[2] Hoffbrand A.V., Weir D.G., "The history of folic acid", British Journal of Haematology, 113, 579-589, 2001.

[3] Werner-Felmayer G., Golderer G., Werner E.R., "Tetrahydrobiopterin biosynthesis, utilization and pharmacological effects”, Current Drug Metabolism, 3, 159-173, 2002.

[4] Rossi M., Amaretti A., Raimondi, S., "Folate Production by Lactic Acid Bacteria", Nutrients, 3, $118-134,2011$

[5] Stralsjö L., "Evaluation of a RPBA method to study the effects of cultivar, ripeness, stroge and processing- folates in berries”, Sweden University Agriculture Science, Uppsala, 2003.

[6] Quinlivan E.P., Hanson A.D., Gregory J.F., "The analysis of folate and its metabolic precursors in biological samples”, Analytical Biochemistry, 348, 163-184, 2006.

[7] Sipahi H., "Folat düzeylerinin mikrobiyolojik yöntemle saptanması, klinik ve toksikolojik açıdan değerlendirilmesi”, Hacettepe Üniversitesi, Fen Bilimleri Enstitüsü, Yüksek Lisans Tezi, Ankara, 2006.

[8] Indrawati R., Verlinde P., Ottoy F., Van Loey A., Hendrickx M., "Implications of $\beta$ mercaptoetanol in relation to folate stability and to determination kinetics during processing: a case study on [6S]-5-methyltetrahydrofolic acid", Journal of Agricultural and Food Chemistry, 52, 8247-8254, 2004.

[9] Gregory JF., "Dietary folate in a changing enviroment: bioavailability, fortification, and requirements", Journal of Food Science, 69(1), 59-60, 2004.

[10] Kamen B., "Folate and antifolate pharmacology", Seminars in Oncology, 24(5), 18-39, 1997.

[11] Molloy A.M., "Folate bioavailability and health", International Journal for Vitamin and Nutrition Research, 72(1), 46-52, 2002.

[12] Gregory J.F., "Bioavailability of folate", European Journal of Clinical Nutrition, 51, 54-9, 1997.

[13] Shane B., "Folate chemistry and metabolism in folate in health and disease", Bailey, L.B., ed., Marcel Dekker, New York, pp.1-22, 1995.

[14] Wagner C., "Folate binding proteins", Nutrition Reviews, 43(10), 293-9, 1985. 
[15] McNulty H., Pentieva K., "Folate bioavailability", Proceedings of the Nutrition Society, 63, 529-536, 2004.

[16] Caudill M.A., Bailey L.B., Gregory J.F., "Consumption of the folate breakdown product paraaminobenzoylglutamate contributes minimally to urinary folate catabolite excretion in humans: investigation using [13C5]para-aminobenzoylglutamate", Journal of Nutrition, 132(9), 26132616, 2002.

[17] Galivan J., Ryan T.J., Chave K., Rhee M., Yao R., Yin D., "Glutamyl hydrolase: pharmocological role and enzymatic characterization", Pharmacology and Therapeutics, 85, 207-215, 2000.

[18] Anguera M.C., Suh J.R., Ghandour H., Nasrallah I.M., Selhub J., Stover P.J., "Methenyltetrahydrofolate synthetase regulates folate turnover and accumulation", The Journal of Biological Chemistry, 278(32), 29856-29862, 2003.

[19] Cooperman J.M., Lopez R., "The role of histidine in the anemia of folate deficiency", Experimental Biology and Medicine, 227 (11), 998-1000, 2002.

[20] Graham I.M., O’Callaghan P., "Vitamins, Homocysteine and cardiovascular risk", Cardiovascular Drugs and Therapy, 16, 383-389, 2002.

[21] Eskes T.K.A.B., "Abnormal folate metabolism in mothers with Down syndrome off pring", European Journal of Obstetrics and Gynecology and Reproductive Biology, 124, 130-133, 2006.

[22] Zetterberg H., "Methylenetetrahydrofolate reductase and cobalamin genetic polymorfisms in human spontaneous abortion: biological and clinical implications", Reproductive Biology and Endocrinology, 2(7), 1-8, 2004.

[23] Rosenblatt D.S., "Methylenetetrahydrofolate reductase", Clinical and Investigative Medicine, 24(1), 56-59, 2001.

[24] Donnelly J.G., "Folic acid", Critical Reviews in Clinical Laboratory Science, 38(3), 183-223, 2001.

[25] Mason J.B., Choi S.W., "Effects of alcohol on folate metabolism: implications for carcinogenesis”, Alcohol, 35, 235-241, 2005.

[26] Kompis I.M., Islam K., Then R.L., "DNA and RNA synthesis: antifolates", Chemical Reviews, 105, 593-620, 2005.

[27] Said H.M., Mohammed Z.M., "Intestinal absorption of water soluble vitamins: an update", Gastroenterology, 22, 140-146, 2006.

[28] Nöral Tüp Defekti, http://www.labtestsonline.org.tr/understanding/conditions/neural-tube/, 20012013.

[29] Centers for Disease Control and Prevention. Spina Bifida and Anencephaly Before and After Folic Acid Mandate, United States, MMWR, http://www.cdc.gov/mmwr/preview/mmwrhtml/mm5317a3.html,. 2000. 2011-2013.

[30] AFP Yüksekliği, Türkiye, http://www.jinekolojivegebelik.com/2012/01/afp-alfa-feto-proteinyuksekligi. html , 2013. 
[31] Rosequist T.H., Finnel R.H., "Genes, folate and homocysteine in embryonic development", Proceedings of the Nutrition Society, 60(1), 53-61, 2001.

[32] Jang H., Mason J.B., Choi S., "Genetic and epigenetic interactions between folate and aging in carcinogenesis", Journal of Nutrition, 135, 2967-2971, 2005.

[33] Fenech M., "Micronutrients and genomic stability: a new paradigm for recommended dietary allowances (RDAs)", Food and Chemical Toxicology, 40, 1113-1117, 2002.

[34] Verhaar M.C., Wever R.M.F., Kastelein J.J.P., van Loon D., Milstien S., Koomans H.A., Rabelink T.J., "Effects of oral folic acid supplementation on endothelial function in familial hypercholesterolemia", Circulation, 100(4), 335-338, 1999.

[35] Widner B., Leblhuber F., Frick B., Laich A., Artner-Dworzak E., Fuchs D., "Moderate hyperhomocysteinemia and immun activation in Parkinson's disease", Journal of Neural Transmission, 109, 1445-52, 2002.

[36] Mattson M.P., Kruman I.I., Duan W., "Folic acid and homocysteine in age-related disease", Ageing Research Reviews, 1(1), 95-111, 2002.

[37] Demirbaş B., Özkaya M., Çakal E., Çulha C., Gülçelik N., Koç G., Serter R., Aral Y., "Plasma homocysteine levels in hyperthyroid patients”, Endocrine Journal, 51(1), 121-125, 2004.

[38] Hilton J.F., Christensen K.E., Watkins D., Raby B.A., Renaud Y., Luna S., Estivill X., MacKenzie R.E., Hudson T.J., Rosenblatt R., "The molecular basis of glutamate formiminotransferase deficiency", Human Mutation, 22, 67-73. 2003.

[39] Belz S., Nau H., "Determination of folate patterns in mouse plasma, erythrocyte and embryos by HPLC coupled with a microbiological assay”, Analytical Biochemistry, 265, 157-66. 1998.

[40] O’Broin S., Kelleher B., "Microbiological assay on microtitre plates of folate in serum and red cells", Journal of Clinical Pathology, 45, 344-7, 1992.

[41] Wright A.J.A., Finglas P.M., Southon S., "Erythrocyte folate analysis: saponin added during lysis of whole blood can increase apparent folate concentrations, depending on hemolysate $\mathrm{pH}^{\prime}$, Clinical Chemistry, 46(12), 1978-1986, 2000.

[42] Baydar T., "İnsan eritrosit folat düzeylerinin saptanması ve toksikolojik ve klinik öneminin değerlendirilmesi”, Hacettepe Üniversitesi, Fen Bilimleri Enstitüsü, Doktora tezi, Ankara, 1999.

[43] Burtis C.A., Ashwood E.R., Textbook of Clinical Chemistry. 3 th ed., 1693-1697, 2006.

[44] Duch D.S., Bowers S.W., Nichol C.A., "Analysis of folate cofactor levels in tissue using HPLC”, Analytical Biochemistry, 130, 385-392, 1983.

[45] Belz S., Frickel C., Wolfrom C., Nau H., Henze G., "HPLC determination of methotrexate, 7hydroxymethotrexate, 5-methyltetrahydrofolic acid and folinic acid in serum and cerebrospinalfluid”, Journal of Chromatography A, 661, 109-118, 1994.

[46] Wilson S.D., Horne D.W., "HPLC determination of the distribution of naturally occuring folic acid derivatives in rat liver", Analytical Biochemistry, 142, 529-535, 1984.

[47] Hart D.J., Finglas P.M., Caroline A.W., Mellon F., Wright A.J.A., Southon S., "Determination of 5-methyltetrahydrofolate in human plasma and urine by combined liquid chromatography mass spectrometry", Analytical Biochemistry, 305, 206-213, 2002. 
[48] Sybesma W., Van Den Born E., Starrenburg M., Mierau I., Kleerebezem M., De Vos W.M., Hugenholtz J., "Controlled modulation of folate polyglutamyl tail length by metabolic engineering of Lactococcus lactis", Applied and Environmental Microbiology, 69,7101-7107, 2003.

[49] Food chart, http://folicacidnow.net/folic_acid/food_chart.shtml, 2013.

[50] Kanmani P., Kumar R.S., Yuvaraj N., Paar K.A., Pattukumar V., Arul V., "Probiotics and Its Valuable Products", Food Science and Nutrition, 53, 641-658, 2013.

[51] Furet J.P., Quenee P., Tailliez P., "Molecular quantification of lactic acid bacteria in fermented milk products using real-time quantitative PCR”, International Journal of Food Microbiology, 97, 197- 207, 2004.

[52] Leroy F., De Vuyst L., "Lactic acid bacteria as functional starter cultures for the food fermentation industry", Trends in Food Science and Technology, 15, 67- 68, 2004.

[53] Schleifer K.H., Ehrmann M., Beimfohr C., Brockmann E., Ludwig W., Amann R., “Application of molecular methods for the classification and identification of lactic acid bacteria", International Dairy Journal, 5, 1081- 1094, 1995.

[54] Sybesma W., Burgess C., Starrenburg M., Sinderen D., Hugenholtz J., "Multivitamin production in Lactococcus lactis using metabolic engineering", Metabolic Engineering, 6, 109-15, 2004.

[55] LeBlanc J.G., de Giori G.S., Smid E.D., Hugenholtz J., Sesma F., "Folate production by lactic acid bacteria and other food-grade microorganisms", Applied Microbiology, 329-339, 2007.

[56] Giraffa G., Lazzi C., Gatti M., Rossetti L., Mora D., Neviani E., "Molecular typing of Lactobacillus delbrueckii of dairy origin by PCR-RFLP of proteincoding genes", International Journal of Food Microbiology, 82, 163- 172. 2003.

[57] Petti S., Tarsitani G., D'arca A.S.A., "Randomized clinical trial of the effect of yoghurt on the human salivary microflora”, Archives of Oral Biology, 46, 705- 712, 2001.

[58] Rossi M., Amaretti A., Raimondi S., "Folate Production by Probiotic Bacteria", Nutrition, 3, 118-134, 2011.

[59] Holasova M., Fiedlerova V., Roubal P., Pechacova M., "Biosynthesis of folates by lactic acid bacteria and propionibacteria in fermented milk", Czech Journal of Food Science, 22, 175-181, 2004.

[60] Klaus S.M., Wegkamp A., Sybesma W., Hugenholtz J., Gregory J.F., Hanson A.D., “A nudix enzyme removes pyrophosphate from dihydroneopterin triphosphate in the folate synthesis pathway of bacteria and plants”, The Journal Biological Chemistry, 280, 5274-5280, 2005.

[61] KEGG (Kyoto Gen ve Genom Bilgi Merkezi), http://www.genome.jp/kegg/, 2012-2013.

[62] Joint Genom Enstitüsü Mikrobiyal Sekanslama, http://genome.jgi-psf.org/mic_home.html, 20122013.

[63] Pompei A., Cordisco L., Amaretti A., Zanoni S., Matteuzzi D., Rossi M., "Folate Production by Bifidobacteria as a Potential Probiotic Property”, Applied and Environmental Microbiology, 73, 167-179, 2007. 